\title{
TESTAMENTARY INHERITANCE IN COMPARATIVE LAW. A COMPARATIVE VIEW OF TESTAMENTARY PRACTICES AND LEGAL FRAMEWORKS IN ITALY AND LATIN AMERICA
}

\author{
Andreea Buțureanu* \\ “Alexandru Ioan Cuza University”, Iași, Romania, E-mail: bnpcarpusor2021@gmail.com
}

(Received: September 2021; Accepted: November 2021; Published: December 2021)

\begin{abstract}
The practice of making wills is as diverse as it is old. While the legislation in some cultures favors certain principles, others emphasize distinct precepts, all of which are guided in the background by the different cultural views about family and the importance attributed to the surviving spouse. Since the practice of testamentary inheritance is based on the desire to provide care to those left behind by the testator, and not in a few cases, in the absence of a constant income that he used to provide, it is important to identify the logic after which each legislator decides who are vulnerable people and which part of the successoral mass should be attributed to them. In the context of societal change in which the family no longer has the same definitions, the present study conducts a comparative analysis of testamentary practices and legal frameworks in Italy and Latin America in an effort to identify both the common elements that define these two Latin geographical areas, as well as their particularities. This analysis is relevant to the established literature in the field of inheritances by capturing the characteristics of two legal systems that have not received the necessary academic attention.
\end{abstract}

Keywords: testamentary inheritance; will-making in Italy; will-making in Latin America.

\section{Introduction: Succession in the XXI century}

The practice of making wills is recorded as being from the period of the Roman Empire. At its basis, the Roman will be a solemn act by which the head of the family appointed a leader of the group. The establishment of an heir could not be absent from any will. Only later, the will could contain final death dispositions, which were called alike: dowry, freedom, forgiveness, usufruct, etc. (Reid et al., 2015). The will had to cover the entire inheritance. The testamentary inheritance was allowed, as well as the one based on the law, by the same person. Succession by will excluded the legitimate one. The established heir took the place of the head of the family,

${ }^{*}$ Corresponding author: Andreea Buțureanu. E-mail: bnpcarpusor2021@gmail.com

Copyright (C) 2021 The Author(s). Published by VGWU Press

This is an Open Access article distributed under the terms of the Creative Commons BY 4.0 license (Creative Commons - Attribution 4.0 International - CC BY 4.0) which permits unrestricted use, distribution, and reproduction in any medium, provided the original author and source are credited. 
Testamentary Inheritance in Comparative Law. A Comparative View of Testamentary Practices and Legal Frameworks in Italy and Latin America

acquiring this power for the rest of his life (Jakotă, 1993). Long before the emergence of the nation-state, increasingly different views on will and succession, in general, had emerged, circumscribed to each cultural space (Reid et al., 2015).

It is anticipated that during the next two decades, an exponentially larger transfer of funds will emerge between the younger generations and a variety of other aging societies by means of succession (Kelly \& Harding, 2006). Due to socioeconomic and demographic developments, the cultural norms underlying these intergenerational asset and wealth transfers through wills are evolving (Sappideen, 2008). The influence of these significant social and demographic shifts, as well as changes in retirement income levels, property dimension and complexity, on interpersonal transfers, is becoming far greater. The definition of family itself has changed as a result of rising divorce requests, cohabitation and same-sex relationships, which has led to the creation of multiple scenarios in the allocation of the successoral mass, as well as obligations of the beneficiaries. Estate planning is far more challenging, owing to uncertainties about policy changes affecting private and public pensions, as well as the need to plan for possibly rising user fees in health and aged care later in life. Transmission of various and substantial asset holdings, family enterprises, and rural properties pose unique difficulties regarding asset sequencing and time, as well as distribution and transfer rules (Gaffney-Rhys \& Jones, 2013; Gilding, 2005; Tilse et al., 2006). In many societies, norms and prescriptions establish expectations about inheritance, as well as standards and behaviors addressing familial transfers, reciprocity, and other cultural duties.

It is critical for scholars, attorneys, policymakers, and lawmakers to be aware of these developments and how they may affect community expectations around asset transfer. When someone dies intestate or without a valid and current will, their assets are distributed according to the state's legal laws. These provisions may or may not meet the demands of an ever-changing array of family structures and relationships and/or may result in injustice. For instance, the underlying beliefs about family support that underpin intestacy regulations do not always apply to all cultural groups (Vines, 2011). In the case that an intestate estate is contested under family provision law, a court may order a different distribution of the assets based on the conditions set forth in the legislation. This process can add to the cost and difficulties already experienced by families.

\section{Methodology}

The present study approaches the practice of testamentary inheritance in Italy and Latin America from the perspective of the following aspects: the formalities 
Buțureanu, A., (2021)

Testamentary Inheritance in Comparative Law. A Comparative View of Testamentary Practices and Legal Frameworks in Italy and Latin America

necessary for the succession, the quotas available for testing, reserved heirs; the role of the surviving spouse and the types of will be specified in local law.

\section{Case study Italy: empirical results}

According to art. 587 of the Italian Civil Code, the will is a revocable act by which a person disposes of, for when he will no longer be alive, of all his goods or a part of them (Capozzi, 2015).

Wills that contain non-patrimonial provisions are also valid, even if there are no patrimonial dispositions in that will.

The testamentary dispositions can be with universal title, if they contain a universality or a share of the testator's assets and confer the quality of heir and with a particular title, when they contain well-determined goods and confer the quality of legatee.

Provisions containing certain goods or a complex of goods do not exclude the possibility that the will is universal, as long as the testator intended to assign the goods as a share of the entire patrimony.

If the legal succession is in the best interest of the family, the testamentary succession is in the individual interest of the testator, non-economic, by which he establishes the "destination" of his patrimony after death.

As in Romanian law, conjunctive wills are not allowed in Italian law. According to art. 589 of the Italian Civil Code, the will of two or more persons cannot be made in the same document, neither in favor of a third person nor reciprocally.

The succession in Italy has as fundamental characteristics the supreme respect given to the family of the deceased person, as well as a specific bureaucratic approach for the validation of the existing members of the family who may have an interest in the estate. All the details of the succession are governed by the Italian Civil Code in Articles 456-809 ("Delle Successionni"), of which Articles 587-712 govern the testamentary inheritance.

The first step in starting the succession procedure is to gather all the relevant documents and complete the declaration of succession ("Dichiarazione di Successione"). In addition to the death certificate, these documents consist of:

- An affidavit on the situation of the family of the deceased: this is a public act by which a depositor makes a statement in the presence of witnesses regarding the family tree of the deceased's family, thus identifying family members who may be interested in the succession procedure.

- Property titles of the goods and lands that are the object of the succession and any other documents related to modifications or works to such properties (extensions and extensions, guarantee certificates, plans, parceling). 
Testamentary Inheritance in Comparative Law. A Comparative View of Testamentary Practices and Legal Frameworks in Italy and Latin America

- A family certificate of the deceased person: a document issued by the Civil Archive Register belonging to the municipality corresponding to the address of the deceased person. From such a certificate can be proved the identity of the heirs, as well as their right to the estate. This certificate contains information on the whole family, providing data on the names of members, their relationships, dates and places of birth, including family members who have moved or died (Studio Commerciale Pelosini Ciampoli, 2011).

According to the Italian laws on inheritance (art. 752-756 of the Italian Civil Code), the beneficiaries pass in place of the deceased and are entitled to their share of the fortune, but also enter into possession of the debts of the deceased. If they exceed the value of the entire estate, the heirs may refuse the right of inheritance. Regardless of whether or not there is a will at the time of death, succession is possible only by submitting an application for a right of probation by the heirs within 1 year of the death of the deceased. Any of the heirs - or the executor of the will, if one has been appointed - may delegate a probation lawyer or notary public to deal with these formalities and usually, the costs of this process are attributed to the estate and paid by the heirs proportionally, according to their right to inheritance (Vallariello, 2016). The requested application can be obtained from the Ministry of Finance and all the assets of the deceased must be taken into account, regardless of whether they are in Italy or abroad. There are complex rules of private international law governing the relationship between assets and beneficiaries and, from a fiscal point of view, there are usually bilateral treaties that determine the debts of foreign beneficiaries of an Italian inheritance, whether we are talking about a legal or testamentary inheritance, both having as benchmarks the rules of the Civil Code (Tonalini, 2017). The request for probation is sent to the competent tax authority ("Agenzia delle Entrate"), and the beneficiaries will be obliged to pay the inheritance tax: usually, this tax includes inheritance tax (depending on the value of the property and the relationship with the deceased) and taxes on the transfer of ownership (property tax and cadastral tax), which do not normally exceed 3\% of the value of goods (Shibata, 2021).

In addition to personal data on death and heirs, the probation application involves:

a) detailed description of the inherited goods;

b) details regarding the payment of taxes (mortgage and cadastral taxes) provided by the heirs, together with copies of the existing receipts for this purpose

c) the payment of the amount of 168 EUR for the mortgage and cadastral taxes, in case the beneficiary of the real estate property will use it as the main dwelling. 
Buțureanu, A., (2021)

Testamentary Inheritance in Comparative Law. A Comparative View of Testamentary Practices and Legal Frameworks in Italy and Latin America

It is also necessary to attach the following to the probation application:

$>$ the death certificate of de cujus, which must be translated into Italian, if the death occurred abroad;

$>$ the family certificate of the deceased person and the heirs and relatives;

$>$ the original or legalized copy of the will, translated into Italian, in case of testamentary succession. Within 30 days from the date of filing the application, the lawyers or executors of the inheritance must submit to the Territorial Agency the application for the "cadastral vault", which is a request for modification of the cadastral details in the property registration documents. Through the "vulture" application process, the Italian financial administration is officially informed that the assets (both land and property) have been transferred from the deceased to his heirs or to all the legatees named in the will, where applicable.

With regard to marriage and partnership, it is important to point out that Italian law applies different provisions depending on the case, determined by the regime in which the spouses found themselves, as follows:

$>$ Spouses married in the regime of the communion of property: upon the death of one of the spouses, the surviving spouse inherits an indivisible half of the total property included in the communion. Excluded from these assets are those that were received as a gift or by inheritance by one of the spouses during the marriage (Griffo, 2016).

$>$ Spouses married in the regime of separation of property: in the process of succession, only the property on behalf of the deceased spouse is to be considered. As a result, if the house is in the name of both spouses and there are no children, the spouse inherits $50 \%$. On the other hand, a home previously purchased by the deceased in his or her sole name will be inherited $100 \%$ by the surviving spouse. Bank accounts, if not in the name of both spouses, will be inherited $100 \%$ by the surviving spouse (Griffo, 2016).

$>$ Spouses married in the separation regime by mutual agreement: the surviving spouse retains all rights over the assets considered part of the succession.

> Married spouses, but in legal separation: under Article 548, paragraphs 2 and 3 of the Italian Civil Code, a spouse who has been charged with separation by a final judgment is entitled to a life annuity only if at the time of the opening of the succession maintenance of her deceased husband, and provided that the estate is sufficient to guarantee this payment for the rest of his life. The annuity is proportional to the estate, with the quality and number of legitimate heirs and will not be at a higher level than the food supply. 
Testamentary Inheritance in Comparative Law. A Comparative View of Testamentary Practices and Legal Frameworks in Italy and Latin America

$>$ Divorce: in case of divorce, the surviving spouse loses all inheritance rights, but the divorce decree must have already been issued before his or her death.

$>$ Civil partnership or cohabitation: although since 2016, Italian laws equate gay marriages abroad with registered civil partnerships, they do not recognize the right to inherit any partner who is not in a marital relationship with the deceased. The death of one of the partners has the effects of a divorce, and in this situation, only through the will can inherit the persons who are in cohabitation relations with de cujus, but in a limited proportion (Vallariello, 2016, p. 22).

The testamentary succession within the Italian inheritance law dates from the tradition of Roman law (Balestra \& Mauro, 2014). It is based on the principle that close members of the deceased person deserve special protection, thus partially limiting the testator's freedom to dispose of his property. As a result, close family members become what are called "forced heirs." Following the testator's death, the will will be published by the competent Italian authorities. A part of the deceased's assets (reserved quota) must necessarily be attributed to the forced heirs - according to art. 536 et seq. Of the Italian Civil Code. The Italian Civil Code determines the available share of the testator's inheritance, meaning the share he can dispose of without any limitation, according to the following table:

Table 1. Succession quotas of the heirs according to art. 536 et seq. of the Italian Civil Code

\begin{tabular}{|c|c|c|}
\hline Heirs & $\begin{array}{l}\text { Quota reserved for heirs } \\
\text { (of the successoral mass) }\end{array}$ & $\begin{array}{l}\text { Quota available } \\
\text { for the will } \\
\text { (of the } \\
\text { successoral } \\
\text { mass) }\end{array}$ \\
\hline Spouse & Half & Half \\
\hline Spouse +1 child & $\begin{array}{l}\text { One third for the spouse, one } \\
\text { third for the family child }\end{array}$ & A third \\
\hline Spouse +2 or more children & $\begin{array}{l}\text { A quarter for the } \\
\text { husband/wife, half for all the } \\
\text { children in the family }\end{array}$ & Quarter \\
\hline Spouse and ascendants & $\begin{array}{l}\text { Half for husband/wife, a } \\
\text { quarter for ascendants }\end{array}$ & Quarter \\
\hline $\begin{array}{l}\text { A surviving child (so in the absence } \\
\text { of a surviving spouse or ascendants) }\end{array}$ & Half & Half \\
\hline $\begin{array}{l}\text { Two or more surviving children } \\
\text { (therefore, there is no surviving } \\
\text { spouse or ascendant of the deceased) }\end{array}$ & Two-thirds & A third \\
\hline
\end{tabular}


Buțureanu, A., (2021)

Testamentary Inheritance in Comparative Law. A Comparative View of Testamentary Practices and Legal Frameworks in Italy and Latin America

\begin{tabular}{|l|l|l|}
\hline $\begin{array}{l}\text { Ascendants of the deceased (in the } \\
\text { absence of a surviving spouse and } \\
\text { children) }\end{array}$ & A third \\
\hline $\begin{array}{l}\text { Spouse, ascendants, siblings of the } \\
\text { deceased }\end{array}$ & $\begin{array}{l}\text { Half for husband/wife, a } \\
\text { quarter for ascendants }\end{array}$ & Quarter \\
\hline $\begin{array}{l}\text { Spouse, brothers and sisters of the } \\
\text { deceased }\end{array}$ & Half for husband, wife & Half \\
\hline $\begin{array}{l}\text { Ascendants, brothers and sisters of } \\
\text { the ascendant }\end{array}$ & One-third for ascendants & Two-thirds \\
\hline Brothers and sisters & $/-$ & All goods \\
\hline
\end{tabular}

Source: Own research.

What can be observed is that although the testamentary freedom is limited to a certain extent, significant shares of the estate are offered to the heirs designated by the will. Another interesting aspect that emerges from the Italian law of testamentary succession is that the brothers and sisters of the deceased are not reserved heirs even if they are the only living relatives. As such, unless the testator explicitly specifies that his siblings receive a portion of the estate, they will inherit according to the quotas specified in the last column of the table above.

Naturally, the situation is completely different in the case of legal inheritance, where we find the following distribution of the succession mass:

- If there is no surviving spouse or spouses are separated and the family has no children, but the deceased siblings and their descendants have survived, each of these categories of heirs receives half of the estate (Balestra \& Mauro, 2014, p. 50).

- If no other category of heirs exists, the brothers and sisters of the deceased are entitled to the entire succession table, together with their children. In the extreme situation, if no member of the family of the deceased of any degree of kinship is alive, the property passes into the possession of the state, which, however, will not pay the taxes related to it if they exceed the value of the inheritance.

- If they are surviving children of de cujus, they are entitled to equal shares in the inheritance.

- Where there is a surviving spouse and children, as well as grandchildren, the husband receives one-third of the estate, and the rest of the descendants receive two-thirds, which will be divided equally between them (Balestra \& Mauro, 2014).

- If the deceased has no living ascendants, no children or siblings, the surviving spouse has the right to all inheritance. 
Testamentary Inheritance in Comparative Law. A Comparative View of Testamentary Practices and Legal Frameworks in Italy and Latin America

- If the family has no children but is a surviving spouse, as well as the parents and siblings of the deceased, the spouse is entitled to $2 / 3$ of the inheritance, $3 / 12$ goes to the parents receiving (1/8 each if both survive) and $1 / 12$ brothers/sisters/grandchildren in equal parts. Stepbrothers receive half of what natural relatives inherit (Iaccarino, 2017). As a remark, it can be seen that the surviving spouse has a privileged share only if the family does not have children. Following the latest regulations published by the Italian Supreme Court, however, the right of the surviving spouse to use the matrimonial home, as well as its assets, is prioritized, therefore it must be excluded from the estate before calculating the inheritance shares at which they have the right of the surviving spouse and the other beneficiaries.

Returning to the testamentary inheritance, it can be transmitted through the following instruments, which are the subject of the following typology:

- The holographic will: must be handwritten, dated and signed by the testator, and must contain the date and place of its writing (Iaccarino, 2017). All individuals in possession of a holographic will must hand it over to a notary, in order to publish it as soon as he became aware of the testator's death. Persons with an interest in the will can challenge the testamentary dispositions in court.

The public notary will proceed to publish the will in the presence of two witnesses, drafting a report in which he will record his condition, will reproduce the content, if it was presented closed or sealed, and the report is signed by the person who handed it to the notary.

If the will has been deposited by the testator in the archives of a notary, the notary will perform the advertising operations.

The public notary will announce the opening of the succession of the competent court. He will also announce, in the case of public and holographic wills, the heirs and legatees immediately after the testator's death (Tagliaferri et al., 2016).

- The notarial will - which can be either public or secret. The public will is recorded by a notary, in the presence of two witnesses. The testator submits to the notary his wishes regarding the successoral mass in the presence of witnesses, and the notary drafts the will. The document must indicate the place, date of acceptance and date of signing and must be signed by the testator, witnesses and notary (Tagliaferri et al., 2016).

Until August 2015, the secret will could be written by another person or by electronic means (Del Giudice, 2018). However, it was considered that this may encourage the creation of false wills, even if the testator's signature was on each page of the document. An essential condition that secret wills must comply with is that they be 
Buțureanu, A., (2021)

Testamentary Inheritance in Comparative Law. A Comparative View of Testamentary Practices and Legal Frameworks in Italy and Latin America

sealed, whether they are in an envelope or not so that the opening of the document is done without breaking or altering it (Del Giudice, 2018). Another fundamental requirement is that the will must be handed to the notary in the presence of two witnesses, and the testator will declare that the document contains his will. The notary will write the fact that he received the will on the outside, the document being subsequently signed by him, the testator and the witnesses.

If the testator can neither write nor read, he will not be able to opt for the secret will. In the case of the mute or the deaf, the testator has to declare in writing that he has read the will if it was written by another person (Capozzi, 2015).

The holographic will is null if it is not written and signed by the testator's hand, and in the case of the public will if the testator's statement, his signature, or the witnesses' are missing.

In the case of a secret will, if some of the specific elements are missing, it is valid as a holographic will.

The holographic and secret will can be withdrawn from the deposit of the notary to whom they were handed. Its delivery is done by signing a report by a notary, testator and witnesses. If the testator cannot sign, a mention is made (Capozzi, 2015).

If it is deposited in a public archive, the report is drawn up by the archivist and signed by the testator and witnesses.

\section{- Special wills}

$\bigcirc$ Wills in times of contagious illnesses, public calamities, or fortuitous events

If the testator is in a situation where, for the above reasons, he cannot make a will by ordinary means, he will be able to hand over the document to the notary, the mayor, or an authority, in the presence of two witnesses, not younger than sixteen years old.

The will is written and signed by the person before whom it is made and signed by the testator and witnesses. If they cannot sign, the reasons shall be recorded in writing.

This type of will no longer takes effect three months after the termination of the case that prevented the testator from resorting to one of the ordinary wills.

If the testator has died, it must be deposited in the archives of a notary in the area where it was made (Tagliaferri et al., 2016).

- Wills on board ships: it may be handed over to the commander or the one immediately below his rank. It is signed and handed over in the presence of two witnesses by the person who received it and its receipt is mentioned in the logbook.

132 S sciendo Journal of Legal Studies Volume 28 Issue 42/2021

ISSN 2457-9017; Online ISSN 2392-7054.

Web: publicatii.uvvg.ro/index.php/jls. Pages $124-141$ 
Upon landing in the country of origin, the master shall hand over all copies of the document to the local maritime authority. The maritime authority or the local consulate must draw up a report which it must send to the Ministry of Defense or the Ministry of the Commercial Navy, after receiving it on board the passenger or commercial ship. Like a will made in the event of a contagious illness, public calamity, or accident, a will made on board a ship loses its validity three months after the testator lands in a place where he could make an ordinary will.

\section{- The will on board the aircraft}

In this case, it is necessary to deliver the will to the commander in the presence of one or two witnesses, if possible. The receipt of the will is mentioned in the logbook (Tagliaferri et al, 2016).

\section{- The will of the military and those assimilated to them}

It can be given in the presence of an official to a representative of the Red Cross or a high-ranking military man, in the presence of two witnesses and signed by all. The will must be sent to the competent Ministry of Defense, which stores it in the archives of a notary office at the domicile or last residence of the testator. This type of will is allowed to the military in times of war or prisoners. Its effects shall cease within the same period of three months and under the same conditions. All such wills are void unless they have entered the testator's statement or the signature of the person authorized to receive it. A will is invalid in the following cases:

$>$ in case of a secret will: if it was not written by the testator's hand or if his signature is missing;

$>$ in the case of a will drawn up by a notary: if the written version of the testator's statements by the notary is missing or if the will was not signed by the notary or by the testator (Tagliaferri et al, 2016). The will may be declared null and void by any interested party on the basis of any other formal error. At present, the illegitimate sons of de cujus can also inherit - Article 593 of the previous regulation specifying the sole status of legitimate sons has been repealed (Tagliaferri et al., 2016).

In general, testamentary dispositions can be challenged by any interested person in case of malice, violence and error. The error on the reason, either in fact or in law, is the cause of annulment of the testamentary disposition when the reason results from the content of the will and is the only one that determined the testator to order. The action is prescriptive within five years from the date of acknowledgment of the will, violence and error. If the heir or legatee has been incorrectly indicated in the 
Buțureanu, A., (2021)

Testamentary Inheritance in Comparative Law. A Comparative View of Testamentary Practices and Legal Frameworks in Italy and Latin America

content of the deed, it retains its validity, if it is unequivocally clear to whom the testator referred. Issues relating to succession in the international arena are governed by private international law. Italian private international law on succession underwent significant changes on 17 August 2015, when EU Regulation 650/2012 on international successions - in this case, properties with an international element became applicable in Italy and most of Europe (Del Giudice, 2018).

The main element of legislative conflict in Italian inheritance law was that the principle of nationality governed succession, which is why it was replaced by a different legal criterion, that of the law of the country of "habitual residence" of the deceased at the time of death. Unfortunately, however, there is no common definition of "habitual residence", and courts must consider a number of factors in interpreting its meaning, including a full assessment of the deceased's life in the years before his death and at the time of death. sale. We believe that this does not facilitate the issue of succession but makes it all the more difficult to manage as we consider the realities of globalization, in which some people can live an equal number of years in different countries.

Citizenship, the determining factor in previous Italian regulation, was a clear, welldefined and easy-to-assess concept. On the other hand, the "habitual residence" of the deceased is not so easy to establish. This is one of the reasons why it is recommended to make a will in which to explicitly specify the law that will be applicable to the succession. In the long run, the main benefit of the new European regulation is that most European countries will apply the same rules, so as to reduce conflicts between the rules and practices of succession in different jurisdictions of the European Union.

The difference that these testamentary choices make can be substantial because, as we have specified, according to Italian law, the testator's immediate family members have certain protected shares in the estate, which cannot be fully affected by the testamentary provisions. By comparison, there are no such fixed rights in English law, where the testator can dispose of his inheritance as he wishes. Under Italian law, there is no specific legislative requirement for the appointment of representatives to manage the estate - executors, administrators, while in English law this condition exists and is considered sine qua non for succession.

If the deceased was resident in Italy, the Italian inheritance tax ("Imposta sulle Successioni") applies to all property and real estate belonging to the deceased. In the case of persons who were not residents in Italy, inheritance tax refers to property and real estate existing in Italy (Del Giudice, 2018).

This tax is differentiated in the case of heirs according to the degree of kinship with the deceased person, specifying the following deductions (Giambrone Law, 2018):

134 S sciendo $\begin{aligned} & \text { Journal of Legal Studies Volume } 28 \text { Issue 42/2021 } \\ & \text { ISSN 2457-9017; Online ISSN 2392-7054. }\end{aligned}$

Web: publicatii.uvvg.ro/index.php/jls. Pages $124-141$ 
Testamentary Inheritance in Comparative Law. A Comparative View of Testamentary Practices and Legal Frameworks in Italy and Latin America

- $4 \%$ of the value of the estate transferred to the surviving spouse and children of the family, with a deduction of 1 million euros for each beneficiary;

- $6 \%$ of the value of the estate inherited from the brothers and sisters of the deceased, with a deduction of 1 million euros for each beneficiary;

- $6 \%$ - relatives up to the fourth degree of kinship with the deceased and other relatives of the surviving spouse up to the third degree - without any deduction;

- $8 \%$ - third parties (unrelated). Both the fees and the exemptions are calculated according to the Italian inheritance tax regime on the total net value of the assets included in the deceased's assets.

The assets involved in the inheritance procedure are real estate, companies, shares, loans, financial funds deposited in a bank account (Giambrone Law, 2018). For the purpose of slightly lower taxation, it is possible to divide the bare property by usufruct by means of gifts or deeds of sale. Indirect taxation can be reduced by transferring bare property with usufruct withholding. At the time of the usufruct owner's death, the bare property will be automatically consolidated with the usufruct. This consolidation will not be taxable. Also, life insurance policies can be used to reduce the amount of inheritance tax due (Papotti \& Morgigni, 2019).

Naturally, the inheritance can also be refused, most often due to the high debts of the deceased, which exceed the value of the estate (Tonalini, 2017). Acceptance of the inheritance can be an express one if it is manifested by declaring the availability to become an heir; or tacit (art. 476 of the Italian Civil Code), if the heirs behave in such a way that their participation in the succession is implied.

In the testamentary succession, it is considered that the portion of the renouncer's inheritance is donated for the following purposes:

- for replacement, pursuant to Article 688 of the Civil Code: the testator may replace the established initial heir with another person if the heir is unable or unwilling to accept the inheritance

- for succession representation (according to article 467 of the Civil Code);

- for accrescimento ("Accrescimento"): Article 674 of the Civil Code specifies that when several heirs have been nominated in the will, in the universality of the assets, without having determined certain parts - whether equal or not - if one of them they cannot or do not accept the inheritance, its share is added to the others. If several heirs have been stated in the same share, the increase takes place in favor of the others established in the same share - according to Art. 588 of the Italian Civil Code. Apart from wills, all succession agreements are prohibited and void, including those that transfer or relinquish inheritance rights - and here we are talking about the context in which the testator is still alive. The only exception to these succession 
Buțureanu, A., (2021)

"Vasile Goldiș" Western University of Arad

Testamentary Inheritance in Comparative Law. A Comparative View of Testamentary Practices and Legal Frameworks in Italy and Latin America

agreements is "family contracts", called "patti di famiglia". The family contract was established in 2006 to regulate intergenerational transfers of business activity. Through the family contract, the owners of a business or a company can redirect their business or share it with one or more descendants (for example, sons and grandsons). The contractor can thus plan the intergenerational transfer of the enterprise to ensure its functionality. The assignment is free (Papotti \& Morgigni, 2019).

The family contract is a consensual act, with immediate effect and must take the form of a public deed, before a notary public, and all persons who have an inherent right recognized by law (ie forced heirs) are required to participate in the signing.

Although the Italian law does not provide for any internal regulations regarding the establishment of trusts, trusts are recognized in Italy in accordance with Law no. 364 of 16 October 1989, which ratified the Hague Convention of 1 July 1985 on the law applicable to trusts and their recognition. The Italian Civil Code does not list the persons capable of testing, but art. 591 establishes the persons incapable of disposing of by will as minors, judicial interdicts and those who, although not placed under interdiction, for certain reasons do not show discernment at the time of testing. In the case of those unable to dispose of by will, the deed can be annulled and not null and void and can be challenged by the persons concerned within the limitation period of five years from the date of execution of the will. Judicial interdicts (persons placed under interdiction by a final and irrevocable sentence due to mental problems) cannot test, and the interdiction operates from the date of publication of the sentence. Therefore, the will concluded before that date is considered valid, without the possibility of being challenged for lack of discernment (Papotti \& Morgigni, 2019). This happened until the amendment of Criminal Law no. 689 of November 24, 1981 (Capozzi, 2015).

There is also a variant of persons unable to test following a court sentence, different from that of persons placed under interdiction, namely persons who cannot test as a result of an accessory punishment, sentenced to life, in some cases provided by military laws.

According to art. 390 of the Italian Civil Code, the emancipated minor, although he is allowed to carry out commercial operations and administrative acts without the assistance of the curator, cannot test.

The same happens in the case of a minor who at the age of sixteen received permission to marry (art. 84 Italian Civil Code).

The beneficiary of the support administration is a new measure of tutelary protection introduced in Italian law by Law no. 6 of 09.01 .2004 , which limits the subject's capacity or, in some cases, forces him not to be able to conclude some acts without the assistance of the support administrator (Capozzi, 2015).

136 Sciendo Journal of Legal Studies Volume 28 Issue 42/2021

ISSN 2457-9017; Online ISSN 2392-7054.

Web: publicatii.uvvg.ro/index.php/jls. Pages $124-141$ 
Testamentary Inheritance in Comparative Law. A Comparative View of Testamentary Practices and Legal Frameworks in Italy and Latin America

The beneficiary of the support administration will have the full capacity to test if he/she proves that at the time of writing the will he/she was in full capacity to understand and consent to the respective document.

Natural incapacity is valid in the case of unilateral acts between the living and the case of contracts and is a temporary situation that can be caused by various factors, such as drunkenness, delirium, hypnosis, etc. The sanction, in this case, may be a relative nullity. The natural incapacity must be proven to have occurred at the time of testing by the person attacking it (Capozzi, 2015).

The general rule is that persons who exist, are born, can receive by will, when it comes to individuals and entities with legal personality.

From this rule, the legislator also established some exceptions: the right to succeed of entities that do not yet exist, children conceived, given unborn and entities lacking legal personality.

a) Unborn children

Children born unborn but conceived until the date of the opening of the succession may inherit by will. He can also inherit the child of a certain person at the time of the testator's death, even if he was not conceived.

b) Legal persons and entities not legally recognized

Legal entities, public or private, have the capacity to receive by will just as legally unrecognized entities can.

Foundations can be set up even by will, which means that entities that do not yet exist have the ability to inherit by will.

With regard to the limits of the capacity to receive by will, the testamentary dispositions made in favor of the guardian or made after his appointment as guardian and annulled by the request for termination of the appointment are null and void, even if the testator died after approval of cessation of guardianship. The rule also applies to the protector, if the will was made while he was substituting the guardian.

\section{Case study Latin America: empirical results}

Latin American inheritance law is tributary to Spanish law, which limits the rights of the surviving spouse to a larger extent, including in the case of a will, and enshrines the rule of co-consanguinity, which guides the entire logic of successions. The legal provisions regarding the testamentary inheritance seem to have been specially designed to mirror those with the intestate so that the testamentary freedom is very limited here.

As a general rule, the surviving spouse is in the 4th class of heirs and cannot receive a significant share of the wealth in any Latin American country. Traditionally, he is guaranteed the usufruct of the coume house, and the right to full inheritance only if 
Buțureanu, A., (2021)

Testamentary Inheritance in Comparative Law. A Comparative View of Testamentary Practices and Legal Frameworks in Italy and Latin America

he either owns common property - an absolutely natural right because he has invested financially in them - or if there are no other heirs in the direct bloodline. (Deere \& León, 2001).

\section{Chile}

The part available for testing here is a quarter of the estate. Half of the succesoral mass is allocated to the forced heirs: children, grandchildren, ascendants, the surviving spouse. Another quarter of the inheritance is called the "improvement quarter" and can be distributed to the forced heirs at the discretion of the testator.

The will must follow a series of very strict rules, as follows:

$\circ$ The language in which the will is written must be Spanish - a fact that significantly complicates the situation of foreign residents in Chile

- The testamentary deed must go through a specific notarial procedure, and the inheritance debate is mandatory through a lawyer in a court

$\circ$ Witnesses of the will must certify that the deed was made in the municipality and country of the testator

- The will must distribute the inheritance in the following order: direct descendants, grandchildren, ascendants, surviving spouse, brothers and sisters. If this order is not followed, the will becomes void (South American Real Estate News, 2018).

\section{Brazil}

The procedure regarding succession is regulated by the Brazilian Civil Code (Law 10406/2002). Also, the Code of Civil Procedure (Law 5869/1973) establishes procedural rules related to succession. Also, the Code of Civil Procedure (DecreeLaw 4657/1942) contains provisions applicable in cases of succession in the situation where there are heirs of Brazilian citizenship, but also provisions regarding the rights of heirs of other citizenship.

Under Brazilian law, a "reserved share" of the estate must go to the reserved heirs. These are the descendants, the ascendants, the surviving spouse and the collateral relatives. Thus, if there are reserved heirs in life, half of the inheritance is reserved for them. The other half can be freely distributed by will (Global Property Guide, 2019).

In the absence of the will or if the will is considered null and void, the entire inheritance is divided among the reserved heirs.

Ownership of property in the estate belongs primarily to the descendants, together with the surviving spouse (unless the latter has been married to the deceased in the system of universal property or the regime of compulsory separation of property). The surviving spouse receives a share equal to the descendants. 
Testamentary Inheritance in Comparative Law. A Comparative View of Testamentary Practices and Legal Frameworks in Italy and Latin America

If there are no descendants, the property is directed to the ascendants at the same time as the surviving spouse. If there are first-degree ascendants (ie, the testator's grandfather and grandmother), the surviving spouse receives $1 / 3$ of the inheritance. If there are only higher degrees of ascendants (ie great-grandfather, etc.) or only a first-degree ascendant, the surviving spouse receives $1 / 2$ of the inheritance.

If there are no descendants or ascendants, the surviving spouse receives the entire estate. In the absence of descendants, ascendants and surviving spouses, collateral relatives up to the fourth degree of inheritance (Global Property Guide, 2019).

\section{Conclusions}

While the two countries share common Latin roots, the views on testamentary succession are completely different. Both have very limited will freedom, however, Italy allows for a larger allocation of the succesoral mass and has a tradition of recognizing the rights of the surviving spouse. By contrast, in Latin America, the spouse is the least considered within the succession. Last but not least, while the first still enjoys a large diversity of testamentary options in special cases, the latter does not. This can be attributed to the very different developments of the two states, as Italy is known to be one of the oldest countries in the world, while the countries of Latin America have developed as political entities in the XIX century.

Further research should assess the cultural foundations behind the more reduced rights of the surviving spouse in Latin America, as patriarchy has had important influences all over the world, however not to this extent. The rationale behind this idea is that if the rights of the surviving spouse are still not defended here then testamentary freedom is an even further to attain ideal.

\section{Acknowledgments}

The author thanks the anonymous reviewers and editor for their valuable contribution.

\section{Funding}

This research received no specific grant from any funding agency in the public, commercial, or not - for - profit sectors.

\section{Author Contributions}

The entire article was written by Andreea Buțureanu.

\section{Disclosure Statement}

The author has not any competing financial, professional, or personal interests from 
Buțureanu, A., (2021)

Testamentary Inheritance in Comparative Law. A Comparative View of Testamentary Practices and Legal Frameworks in Italy and Latin America

other parties.

\section{References}

1. Amministrazioni di Condominio - mministrazioni Immobiliari (2011). http://www.studiopelosiniciampoli.it/faq/SUCCESSIONE_DOCUMENTAZIONE.pdf

2. Baker, C. Gilding, M., (2011). Inheritance in Australia: Family and charitable distributions from personal estates. Australian Journal of Social Issues, 46, pp. 273-289.

3. Capozzi, C. (2015). Succesioni e donazioni - Quarta editione, Giuffre Editore.

4. Deere, C. D., León, M., (2001) Empowering Women: Land And Property Rights In Latin America, University of Pittsburgh Press, 2001.

5. Del Giudice, C., (2018). New legislation on Italian wills nd international succession why you should revise your Italian will, Italy-UK Law, 2018, http://www.italy-uklaw.com/new-legislation-on-italian-wills-and-international-succession-why-you-shouldrevise-your-italian-will/.

6. Gaffney-Rhys, R., Jones, J., (2013). Where there's a will there's a way: Attitudes to inheritance planning amongst small business owners. International Journal of Law and Management, 55, pp. 103-122.

7. Giambrone Law, (2018). Italian Inheritance Tax Costs Explained, Giambrone Law, https://www.giambronelaw.com/site/international/italian-solicitors/probate-trust-

management/italian-inheritance-tax-amount/.

8. Global Property Guide, (2019). Inheritance tax and inheritance law in Brazil, Globalpropertyguide.com,https://www.globalpropertyguide.com/Latin-

America/Brazil/Inheritance.

9. Griffo, D., (2016). Le successioni causa di morte. Milano: ltalex Editore.

10. Iaccarino, G., (2017). Successioni e donazioni. Assago: UTET Giuridica.

11. Jakotă, V. M. (1993). Drept Roman, vol. II. Iaşi: Editura Fundaţiei „Chemarea”.

12. Kelly, S. Harding, A., (2006). Don't rely on the old folks' money: Inheritance patterns in Australia. Elder Law Review, 5, pp. 1-14.

13. Papotti, R. A., Morgigni, G. G., (2019). IBA International Estate Planning Guide - Italian Chapter. International Bar Association Publications.

14. Reid, K. G. C., Wall, M. J., Zimmermann, R., (2015). Intestate Succesion, Comparative Succesion Law, vol. II. London: Oxford University Press.

15. Sappideen, C., (2008). Families and intergenerational transfers: Changing the old order. UNSW Law Journal, 31, pp. 738-765.

16. Shibata, Y., (2021). Italian Inheritance Law, Mazzeschi.it, https://www.mazzeschi.it/italian-inheritance-law/.

17. South American Real Estate News, (2018). Wills and Inheritance Basics In South America are very different from Western Countries, Gatewaytosouthamerica, https://www.gatewaytosouthamerica-newsblog.com/wills-and-inheritance-basics-in-southamerica-are-different-to-western-countries/.

18. Studio Commerciale Pelosini Ciampoli, (2015). SCHEDA RACCOLTA DOCUMENTI SUCCESSIONE, Consulenza mministrativa Fiscale Finanziaria e del Lavoro.

140 S sciendo Journal of Legal Studies Volume 28 Issue 42/2021 
Buțureanu, A., (2021)

Testamentary Inheritance in Comparative Law. A Comparative View of Testamentary Practices and Legal Frameworks in Italy and Latin America

19. Tagliaferri, V., Preite, F., Carbone, C., (2016). Le succesioni. Milano: Giuffre Editore. 20. Tilse, C., Rosenman, L., Peut, J., Ryan, J., Wilson, J., Setterlund, D., (2006). Managing older people's assets: Does rurality make a difference? Rural Society, 16, 169-185.

21. Tonalini, P., (2017). Eredità, testamento e donazioni. Milano: Edizioni FAG.

22. Vallariello, V., (2016). Disposizioni testamentarie contenuto non patrimoniale e nuove tecnologie informatiche, Teză de doctorat, Universitatea din Firenze, https://flore.unifi.it/retrieve/handle/2158/1103382/276216/Tesi\%20dottorato\%20Valentina $\% 20$ Vallariello.pdf.

23. Vines, P., (2011). Bleak house revisited? Disproportionality in family provision estate litigation in New South Wales and Victoria. Melbourne: Australasian Institute of Judicial Administration Incorporated. 